\section{RI-3 試料計測}

來長 栗原慎一郎（東京女子医大）

\section{In vitro test counting 時の誤差について}

横浜书立大学医学部病院 中央放射線部 ○氏家 盛通・野沢 武夫

In vitro test はますます盛んに行なわれるようになっ て来ており各種操作の自動化も進み精度の向上传力が 続けられている. しかし最後の counting 時にも, 統計 変動, counter の経時変化等による誤差が考えられる. との誤差が計測方法によってどのように変化するかにつ いてインシュリン第血中サイロキシンについて実験を行 なった。それぞれ 8 種のサンプルを作成して，測定時間 $15 \mathrm{sec} \sim 180 \sec (1,200 \sim 50,000$ counts $)$ Kて 25 回 counting を行ない平均値, 最小檤, 最大值, 標準偏差, 変動 率と理諭上の標準偏差を示した。計測時間は他の操作よ り入り得る愦差より小さくなる様に選ぶべきであり，分 割測定，上清沈查の嵲者の測定等を検討しる必要があ る.

\section{2. ラジオイムノアッセイ測定時の温度管理について} 神奈川県立成人病センター 放射線科

○酒井 聡子・根本栄一郎・山本 洋一

ラジオムノアッセイ測定時の多くのバラッキ因子の 中で，操作時の温度について検討した。すなわち市販キ ットの指定条件範国内で, 測定系をすべて $4^{\circ} \mathrm{C} て ゙$ て処理し た時と従来通り反応操作を室温で行なった場合の標準曲 線の变化で検討した。

結末は低温探作の方が空温操作より直線領域が広がり 添付標準曲線との一致すよかった。 又低濃度域の感度が 高まった。一方キットの経時変化も低温操作の方が小さ く操作時間に対して安定がよい. バラッキはインスリン のプール血清 5 種の測定值の平均で約 $\pm 20 \%$ から士 $12 \%$ に改善された。一部低温処理,一部室温処理はバラッキ やすかった。

\section{3. $\mathrm{T}_{3}$ イイムノアッセイ kit の基礎的臨床的検討}

東点都立駒込病院 放射線科

○小笠原 幹・州俊夫・横山 春夫 東京都立大久保病院 放射線科

船橋 哲哉・川上 亮二・柴田 雅義 東京都立萑原病院 放射線科

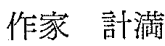

[目的]

RIA を利用した血中トリヨードサイロニンの測定 kit は現在数社より供給されているが，今回我々は $\mathrm{T}_{3}$-IA kit
(RCC) を使用する機会を得たのでその再現性, Incuba- 当 tion 時間及び温度, 他kit（三共エームス，ダイナボッ ト) による $T_{3}$ 測定值との相関, Incnbation 時間につい ては高温で短時間の Incubation の可能性を検討した. [結果]

(1)再現性は良好; (2)Incubation 時間は16時間以上あれ ば影響がない. (3)Incubation 温度は高温でやや高值を示 す傾向はあったが $10^{\circ} \mathrm{C} \sim 30^{\circ} \mathrm{C}$ てはその差はない。(4)室温 で16時間の Incubation を $37^{\circ} \mathrm{C} 1$ 時間に変え得る。(3)他 kit による $\mathrm{T}_{3}$ 測定値と屯良く相関する。

\section{C-peptide RIA（kit の基礎的検討）}

日立製作所日立総合病院、放射線科 RI 室 ○井村 等・佐 藤 㛜 村田 勉・滝田 光代 C-ペプチドキット第1の kit 使用に当り, kitの基礎 的検討を加えた. Incubation 時間 (第 1 反灾時), 24 時 間，48時間では standard curveではあまり差は認めら れずその時温度は上搨 $\left(3^{\circ} \mathrm{C} \sim 10^{\circ} \mathrm{C}\right)$ に從い $\mathrm{B} / \mathrm{BO}$ は各 ポイントで, 上显を示した。血清量の変化は量が增加 $(0.1 \sim 0.3 \mathrm{ml})$ 亿從い下降 curve を示した. 再現性は良 好であった，遠心分㕍はまだ検討する余地がある。次に DCC 法の場合 standard curveは，S状 curve を示し， 二抗体法との再現性は恶く DCC 液の作成（組成）加え る量に問題があり，検討が必要と考える，血清分離は慎 重に行なう（フェブリン混大防止など）．尚実際にIRI值 CPR 值との関係は良好であった，以上有用な kit と考え 马.

85. 血中 Cortisol 測定法について 北海道会社保險中央病院 ○小島孝志・萩原 康司・中川 一枝

Cortisol は副腎皮質で Cholesterol から生侖成され， 分泌される Steroid hormone・の一つで大部分は transcortin と結合して体内を偱環する，その分泌はACTHに より支配されている. Cortisol の測定は，視床部一脳下 垂体一副腎系の機能謗断に有用である．從来測定法は螢 光法が主であるが，近年 CPBA 法. RIA 法，が開発さ れた。今回吾々は CPBA 法を用いた cortipac kit を用 い測定法について種々检討を加え，再現性の良々結果 值を得た. 又間脳下垂体系が正常な場合 ACTH の分泌 変動に伴って，早朝高值，深夜低值という日内変動を示 し，疾病，妊娠，Stress，などにより敏感に影響を受け， 特に副腎系の機能診断に有用な手段之考える。

\section{Tetratab kit $の$ 基礎的臨床的検討}

東索都立大久保病院 放射線科 